\title{
Impact of Oxyfluorfen on Some Anatomic Parameters in the Leaves of Oat Plants (Avena Sativa L.)
}

\author{
Hristo Anastasov
}

Agricultural University, Bulgaria

\begin{abstract}
On the test-field of the Agricultural University - Plovdiv, a field experiment was carried out for the purpose to determine biological effectiveness and selectivity of some soil herbicides in oat plants of the Dunav1 variety. One of them was the Goal $2 E$ herbicide with active ingredient oxyfluorfen $24 \%$.

Oxyfluorfen was introduced at a dose of $100 \mathrm{ml} / \mathrm{dka}$ after planting of oats seeds. During the vegetation period, some visible signs of phytotoxicity in the crop were observed - plant growth inhibition, leaf and vegetation tip deformation, weak chlorosis, etc.

For the purpose to determine the effects of the herbicide on oat leaf anatomy, samples from the midsection of the leaves were taken. The parameters taken into consideration were stomata number $/ \mathrm{mm}^{2}$ and stomata size $(\mu \mathrm{m})$ from the upper and lower epidermis, and size of the assimilation parenchyma (mesophyll) of the leaf.

It was established that oxyfluorfen caused considerable changes in the oat leaf anatomy, which found expression in increase of stomata number $/ \mathrm{mm}^{2}$, as well as reduction of the thickness of leaf lamina (blade), compared to those in the non-treated control plants.
\end{abstract}

Keywords: oxyfluorfen, phytotoxicity, oats leaf anatomy, stomata number $/ \mathrm{mm}^{2}$, mesophyll.

\section{INTRODUCTION}

Herbicides are biologically active chemical compounds with certain toxicity which may cause damage to crops. Phytotoxic action of preparations is the reason for changes in the metabolism of plants, which leads to disruption of their normal rhythm of growth and development. And that may be a prerequisite for the perish of plants.

Oxifluorfen has adverse impact to the content of chloroplasts in plant leaves (Kamble, 2007 a; Jung et al., 2008), which is related to their feeding and causes disruption of biochemical and physiological processes in them (Coble, Slife, 1971; Choi et al., 1998; Warabi et al., 2001; Ha et al., 2003; Jung et al., 2004; Yang et al., 2006). At a later stage of crop plants development anatomical and morphological changes were observed in their tissues and organs, which inhibit the growth and development of plants and may be the cause for their death (Martin, Fletcher, 1972; Muniyappa et al., 1980 ; Bakale, 1989; Ferrel et al., 1989; Tripathi et al., 1992; Mukharji, 1994; Suresh, Muniyappa, 1994; Guh, Kuk, 1997; Yang et al., 2006; Kamble, 2007 b).

The purpose of this study was to determine the impact of oxyfluorfen on some anatomical parameters of the leaves of oat plants.

\section{Materials ANd Methods}

On the test-field of the Agricultural University - Plovdiv, a field experiment was carried out for the purpose to determine the biological effectiveness and selectivity of some soil herbicides in oat plants of the Dunav 1 variety. One of them was the Goal 2E herbicide with active ingredient oxyfluorfen 24 $\%$.

Oxyfluorfen was introduced at a dose of $100 \mathrm{ml} / \mathrm{dka}$ after planting of oats seeds.

During the vegetation period, some visible signs of phytotoxicity in the crop were observed - plant growth inhibition, leaf and vegetation tip deformation, weak chlorosis, etc.

For the purpose of determining the effects of the herbicide on oat leaf anatomy, samples from the midsection of the leaves of the damaged plants and from the untreated control plants were taken and fixed in $70 \%$ Ethanol. To examine the anatomic parameters, an Amplival light microscope was used. 
The parameters taken into consideration were stomata number $/ \mathrm{mm}^{2}$ and stomata size $(\mu \mathrm{m})$ from the upper (adaxial) and lower (abaxial) epidermis, and size of the assimilation parenchyma (mesophyll) of the leaf - all at combined magnification of 400X (10X ocular and 40X objective). 30 measurements of each indicator were carried out.

\section{RESUlTS AND DisCUSSION}

Leafs of oat plants (Avena sativa L.) are linear in shape with parallel fibers. The stomata are located on both sides of the leaf, characterizing it as amphistomatic. Basic epidermal cells are prosenchymatous in shape, with slightly curvy anticlinal walls. Stomata apparatus is of parasite type with two stomata surrounding cells and form of closing cells of stomata is dumbbell like. Closing cells of stomata are at the same level with the neighboring epidermal cells. Stomata surrounding cells are elliptical, arranged parallel to the closing cells.

Mesophilus is homogeneous and represented by isodiametric in shape, scatterly located parenchymal cells, among which there are bigger or smaller intercellular spaces.

The data on impact of oxyfluorfen on some anatomic parameters in the oat plant leaves of the Dunav 1 variety are given in Table 1 . The dimensions of assimilation parenchyma in the leaves of treated plants $(80) 100,33 \pm 1,93(120) \mu \mathrm{m}$ decrease compared to reported values for untreated plants $(67,5) 115,2 \pm 3,42(162,5) \mu \mathrm{m}$. The detected differences in the minimum and maximum values for dimensions of mesophilus of leaves, are due to the impact of herbicides on plants and the adverse impact is confirmed by their average values - 115,2 $\mu \mathrm{m}$ for the control plants and $100,33 \mu \mathrm{m}$ in treated plants. Reduction of the thickness of leaf blades is directly related to nutrition of plants.

Table1: Impact of oxyfluorfen on some anatomic parameters in the leaves of oat plant (Avena sativa L.)

\begin{tabular}{|c|c|c|c|c|c|c|c|}
\hline \multirow{2}{*}{\multicolumn{2}{|c|}{$\begin{array}{l}\text { Indexes } \\
\text { Variants }\end{array}$}} & $(\min ) \bar{x} \pm \mathrm{S} \bar{x}(\max )$ & $\mathrm{S}, \%$ & $\max : \min$ & $(\min ) \bar{x} \pm \mathrm{S} \bar{x}(\max )$ & $\mathrm{S}, \%$ & $\max : \min$ \\
\hline & & \multicolumn{3}{|l|}{ non treated } & \multicolumn{3}{|c|}{ treated } \\
\hline & $\begin{array}{c}\text { leaf } \\
\text { parenchyma } \\
\text { (mesophyll), } \\
\mu \mathrm{m}\end{array}$ & $(67,5) 115,2 \pm 3,42(162,5)$ & 16,28 & 2.41 & $(80) 100,33 \pm 1,93(120)$ & 10,58 & 1,5 \\
\hline \multirow{3}{*}{$\begin{array}{c}\text { ad } \\
\text { epidermis }\end{array}$} & number $/ \mathrm{mm}^{2}$ & $(33,3) 49,2 \pm 1,45(66,6)$ & 16,26 & 2,0 & $(41,6) 58,9 \pm 1,38(75)$ & 12,83 & 1,8 \\
\hline & length, $\mu \mathrm{m}$ & $(57,5) 59,5 \pm 0,38(62,5)$ & 3,56 & 1,08 & $(52,5) 58 \pm 0,70(67,5)$ & 6,63 & 1,28 \\
\hline & width, $\mu \mathrm{m}$ & $(27,5) 33,41 \pm 0,33(37,5)$ & 5,37 & 1,36 & $(27,5) 29,25 \pm 0,34(32,5)$ & 6,41 & 1,18 \\
\hline \multirow{3}{*}{$\begin{array}{l}\text { ab epidermis } \\
\text { stomata }\end{array}$} & number $/ \mathrm{mm}^{2}$ & $(33,3) 41,38 \pm 0,93(50)$ & 12,38 & 1,5 & $(33,3) 52,8 \pm 1,81(66,6)$ & 18,7 & 2,0 \\
\hline & length, $\mu \mathrm{m}$ & $(65) 68,16 \pm 0,49(72,5)$ & 3,96 & 1,11 & $(50) 58,33 \pm 0,77(65)$ & 7,23 & 1,3 \\
\hline & width, $\mu \mathrm{m}$ & $(27,5) 29,25 \pm 0,29(32,5)$ & 5,56 & 1,18 & $(25) 28,08 \pm 0,31(30)$ & 6,04 & 1,2 \\
\hline
\end{tabular}

Due to the impact of oxyfluorfen, number of stomata per unit of area in the upper and lower epidermal layers increases. For adaxial epidermal cells results are $(33,3) 49,2 \pm 1,45(66,6)$ number of stomata per $\mathrm{mm}^{2}$ in untreated plants and $(41,6) 58,9 \pm 1,38(75)$ number/ $\mathrm{mm}^{2}$ stomata in treated plants, while for abaxial epidermal cells, the number of stomata is $(33,3) 41,38 \pm 0,93(50)$ in the control and $(33,3) 52,8 \pm 1,81(66,6)$ number $/ \mathrm{mm}^{2}$ in the treated plants. Regarding the size of the stomata, reduction of their values to certain extent is reported for the treated plants and atrophy of their closing cells is observed, which is associated with the efficiency of their functioning.

Reduction of the thickness of the assimilation parenchyma of leaves, increase in the number of stomata per unit of area and reduction of their size as well as the atrophy of their closing cells, in the plants treated with oxyfluorfen, is the cause for the established dramatic retention of the growth and development of oat plants which is manifested by Dwarf-like shape of plants.

\section{Conclusions}

Negative impact of oxyfluorfen on some anatomical parameters in the leaves of oats is expressed in reduction of the thickness of the leaf blade, increase of the number of stomata per $\mathrm{mm}^{2}$ in the upper and the lower epidermal layers of the leaf and reduction of their size as well as atrophy of the closing cells of stomata. 


\section{REFERENCES}

[1] Bakale, V.L. (1989). Spray effects of herbicides on Xanthium strumarium Linn. The Botanique, 10 (1-4), pp. $53-65$.

[2] Choi, K.W., Han, O., Lee, H.J., Yun, Y.C., Moon, Y.H., Kim, M., Kuk, Y.I., Guh, J.O. (1998). Generation of resistance to the diphenyl ether herbicide, oxyfluorfen, via expression of the Bacillus subtilis protoporphyrinogen oxidase gene in transgenic tobacco plants. Biosci. Biotechnol. Biochem.,62, pp. 558 - 560.

[3] Coble, H.D., Slife, F.W. (1971). Root diffusions in Ampelamus albidus caused by 2,4-D. Weed Science, 19, pp. $1-3$.

[4] Ferrel, M.A., Whittson, T.D., Alley, H.P. (1989). Control of Euphorbia esula with growth regulators herbicide combinations. Weed Technology, 3, pp. 479 - 484.

[5] Guh, J.O., Kuk Y.I. (1997). Difference in absorption and anatomical responses to protoporphyrinogen oxidaseinhibiting herbicides in wheat and barley. Korean Journal of Crop Science 42(1), pp. $68-78$.

[6] Ha, S.B., Lee, S.B., Lee, D.E., Guh, J.O., Back, K. (2003). Transgenic rice plants expressing Bacillus protoporphyrinogen oxidase gene show low herbicide oxyfluorfen resistance. Biol. Plant., 47, pp. $277-280$.

[7] Jung, H.I., Kuk, Y.I., Back, K., Burgos, N.R. (2008). Resistance pattern and antioxidant enzyme profiles of protoporphyrinogen oxidase (PROTOX) inhibitorresistant transgenic rice. Pesticide Biochemistry and Physiology, 91(1), pp. $53-65$.

[8] Jung, S., Lee, Y., Yang, K., Lee, S.B., Jang, S.M., Ha, B., Back, K.(2004). Dual targeting of Myxococcus xanthus protoporphyrinogen oxidase into chloroplast and mitochondria and high level oxyfluorfen resistance. Plant Cell Environ, 27, pp. 1436 - 1446.

[9] Kamble, S.I. (2007 a). Effect of spray application of oxyfluorfen on anatomical characters of Hibiscus cannabinus Linn. Biosciences Biotechnology Research Asia, 4(2), pp. 671- 674.

[10] Kamble, S.I. (2007 b). Effect of spray application of 2,4-D on morphological characters of Hibiscus cannabinus Linn. Biosciences Biotechnology Research Asia, 4(2), pp. 705 - 712.

[11] Martin, J.A., Fletcher, J.J.(1972). The effect of sublethal doses of various herbicides on lettuce. Weed Res, 12, pp. 268 - 271.

[12] Mukharji, A. (1994). Effects of certain phenoxy herbicides on mortality, growth and seed output of Abutilon indicum(Linn.) S.W. Acta Botanika Hungarika, 38 (1-4), pp. 335 - 343.

[13] Muniyappa, T.V., Ramchandra Prasad, T.V., Krishnamurthy, K.(1980). Comparative effectiveness of mechanical and chemical method of control of Parthenium hysterophorus Linn. Indian J. Weed Sci, 12(2), pp. 137 - 144.

[14] Suresh Babu, V., Muniyappa, T.V. (1994). Comparative efficacy of post-emergent herbicides on the control of Solanum elaegnifolium. Indian J. Agron. Sci, 26, (3-4), pp. 22 - 27.

[15] Tripathi, B., Verma, T.S., Sharma, H.L. (1992). Chemical control of Lantana camera and its use as organic manure. Indian J. Agron. Sci, 37 (1), pp. 135 - 139.

[16] Warabi, E., Usui, K., Tanaka, Y., Matsumoto, H. (2001). Resistance of a soybean cell line to oxyfluorfen by overproduction of mitochondrial protoporphyrinogen oxidase. Pestic. Manag.Sci., 57, pp. 743 - 748.

[17] Yang, K., Jung, S., Lee, Y., Back, K. (2006). Modifying Myxococcus xanthus protoporphyrinogen oxidase to plant codon usage and high level of oxyfluorfen resistance in transgenic rice. Pestic. Biochem. Physiol., 86, pp. 186 - 194. 